\title{
Potency of sponge-associated bacteria producing bioactive compounds as biological control of vibriosis on shrimp
}

\section{Potensi bakteri penghasil senyawa bioaktif yang berasosiasi dengan spons sebagai biokontrol penyakit vibriosis pada udang}

\author{
Adityawati Fajar Rini ${ }^{1}$, Munti Yuhana ${ }^{2}$, Aris Tri Wahyudi ${ }^{1 *}$ \\ ${ }^{1}$ Program Studi Mikrobiologi, Departemen Biologi, Fakultas Matematika dan Ilmu Pengetahuan Alam \\ Institut Pertanian Bogor, Jalan Agatis, Kampus IPB Darmaga, Bogor 16680 \\ ${ }^{2}$ Departemen Budidaya Perairan, Fakultas Perikanan dan Ilmu Kelautan, Institut Pertanian Bogor \\ Jalan Agatis, Kampus IPB Darmaga, Bogor 16680 \\ Korespondensi: aristri2011@gmail.com
}

\begin{abstract}
The aims of this study were to obtain sponge-associated bacteria as biocontrol to inhibit vibriosis in vitro and in vivo, to identify the bacterial isolates based on 16S-rRNA gene, and to detect the presence of nonribosomal peptide synthetase (NRPS), and polyketide synthase (PKS) genes to prove its ability of bioactive compounds synthesis. Aaptos sp. and Hyrtios sp. sponges were collected from Pramuka Island, Jakarta. The isolation using sea water complete (SWC) and zobel marine agar (ZMA) medium obtained 174 isolates. A total 69 isolates were screened successfully based on their antibacterial activity. 47 isolates showed negative haemolysis through hemolytic assays. The pathogenicity test used twelve selected isolates that have a broad spectrum of antibacterial activity and haemolysis negative. The result of pathogenicity test showed that 12 isolates were not pathogenic to the shrimp post larvae with no significantly different $(\mathrm{P}>0.05)$ between treatment and negative control. Results of challenge test with Vibrio harveyi have a significant difference survival $(70 \pm 5.0-90 \pm 0.0 \%)(\mathrm{P}<0.05)$ compared with positive control $(38.3 \pm 2.9 \%)$. Genetic analysis based on 16S-rRNA revealed the groups of three genera belonged to Pseudomonas, Staphylococcus, and Alcaligenes. Based on amplification of NRPS and PKS genes, four bacterial isolates have been detected to have only NRPS gene, one isolate has only PKS, and one isolate has both genes. The results indicate that the potency of six sponge-associated bacteria as bioactive compounds producers.
\end{abstract}

Keywords: NRPS, PKS, anti-vibriosis, Pacific white shrimp

\begin{abstract}
ABSTRAK
Penelitian ini bertujuan untuk memperoleh isolat bakteri asosiasi spons yang mempunyai kemampuan dalam menghambat vibriosis secara in vitro, in vivo dan mendeteksi gen 16S-rRNA, nonribosomal peptide synthase (NRPS) serta polyketide synthase (PKS) untuk memastikan kemampuan mensintesis senyawa bioaktif. Spons Aaptos sp. dan Hyrtios sp. berhasil dikoleksi dari perairan Pulau Pramuka, Kep. Seribu Jakarta. Isolasi bakteri dengan menggunakan media sea water complete (SWC) dan zobel marine agar (ZMA) diperoleh 174 isolat. Sebanyak 69 isolat terdeteksi memiliki aktivitas antibakteri. Uji hemolisis menunjukkan 47 isolat adalah hemolisis negatif. Uji patogenisitas menggunakan 12 isolat terpilih yang memiliki spektrum luas dan hemolisis negatif. Hasil uji patogenisitas tehadap 12 isolat menunjukkan bahwa semua isolat tidak bersifat patogen terhadap pascalarva udang vaname. Hal ini dibuktikan dengan sintasan pascalarva udang vaname yang tidak berbeda nyata $(\mathrm{P}>0,05)$ dengan kontrol negatif. Hasil uji tantang terhadap Vibrio harveyi diketahui sintasan pascalarva udang vaname $(70 \pm 5,0-90 \pm 0,0 \%)$ memiliki perbedaan yang signifikan jika dibandingkan dengan kontrol positif $(38,3 \pm 2,9 \%)$. Berdasarkan analisis sekuen gen 16S-rRNA, menunjukkan bahwa isolat-isolat tersebut memiliki kemiripan dengan genus Pseudomonas, Staphylococcus, dan Alcaligenes. Deteksi gen NRPS dan PKS menggunakan PCR diperoleh empat isolat bakteri memiliki hanya gen NRPS, satu isolat memiliki hanya gen PKS, dan satu isolat memiliki kedua gen NRPS-PKS. Hal ini membuktikan bahwa keenam isolat memiliki potensi sebagai penghasil senyawa bioaktif.
\end{abstract}

Kata kunci: NRPS, PKS, antivibriosis, udang vaname 


\section{INTRODUCTION}

Vibrio sp., which causes vibriosis, is a common disease in aquaculture. The bacteria can virtually infect all kind of marine organisms, resulting in mass death (Isnansetyo et al., 2009), and it usually attacks shrimp at the stage of larval, protozoea, causing massive losses, that can reach $80-85 \%$ of the total production (Chatterjee \& Haldar, 2012; Aguirre-Guzmán et al., 2013). Infected shrimp are generally characterized by clinical symptoms such as dark red or pale color, red antennae, and legs (Felix et al., 2011). Vibrio species classified as pathogenic included: $V$. anguillarum, $V$. alginolyticus, V. parahaemolyticus, V. carchariae, V. cholerae, V. damsela, V. fluvialis, V. furnissii, $V$. metschnikovii, V. mimicus, V. vulnificus biotype 2, and $V$. damsela (Listonella damsela). The latter one was re-classified in Photobacterium damselae sub species Damselae and V. carchariae (which is a synonym for $V$. Harveyi) (Austin, 2010).

Antibiotics are being widely used in controlling vibriosis, but they have negative impacts on the environment such as bacterial resistance and residue accumulation in the fishery products. Vibrio has been demonstrated to be resistant to almost all kind of antibiotics available on the market (Isnansetyo et al., 2009). The problems addressed above can be overcome through efforts in searching for antibacterial compounds sources with improved properties in order to bring pathogenic Vibrio bacteria under control.

Sponges are sea macro invertebrates, which are a source of bioactive compounds with a wide range of biomedical potential. Bioactive compounds extracted from sponges and its associated microbes can be used to develop new medicines and natural products. Bioactive compounds, that were identified in sponges, were observed to have some medicinal benefits such as anticancer, antibacterial, antifungal, anti-inflammatory, antimalarial, and anti-virus (Mayer et al., 2011).

Using bacteria that live in association with the sponge was shown to be better, since the bacteria can be purified and cultured at a laboratory scale, and do not need to be collected from wild (Abubakar et al., 2011). Microbes use sponge porous body not only as habitat, but also as a protection against predators, and they further contribute to the sponge defense system by excreting antibiotics and bioactive substances (Taylor et al., 2007). Nowadays, research for new bioactive compounds in bacteria generally focuses on the exploration of the genes encoding bioactive compounds, including nonribosomal peptide synthetase (NRPS) adenylation and polyketide synthase (PKS) ketosintase that have conserved adenilase (A) domain and ketosynthase (KS) domain, respectively. The use of KS and A domains in diversity studies was a consequence of the use of these domains in modules and were observed to have a high degree of conservation compared to others (Moffit \& Neilan, 2003).

Sponge-associated bacteria is expected to be the source of bioactive compounds controlling pathogenic bacteria, especially Vibrio sp. in shrimp farming. Thus, this study was conducted to obtain sponge-associated bacteria that have the ability to inhibit Vibrio sp. in vitro, in vivo, and to identify the bacteria based on 16S-rRNA gene, and to detect the genes encoding bioactive compounda (NRPS and PKS genes).

\section{MATERIALS AND METHODS}

\section{Materials}

The materials used were: $V$. parahaemolyticus ATCC 17802 bacterial isolates, V. vulnificus 195B (collected from Laboratory of Fish Quarantine Standard Quality Test Control and Fishery Safety), V. harveyi P-275 (collected from the Research and Development Laboratory of Brackish Aquaculture Water, Maros), Bacillus subtilis, Escherischia coli ATCC 8739 (from the collection of the Laboratory of Bogor Agricultural Culture Collection (IPBCC), and post larvae Pacific white shrimp Litopenaeus vannamei brought from PT. Suri Tani Pemuka Carita hatchery, Pandeglang, Banten.

\section{Sampling method}

Sponges were randomly collected on Scout Island (Thousand Islands, Jakarta) with the permission of the Thousand Islands National Park. They were gathered using two collecting methods: snorkeling at 1-3 m deep and SCUBA diving at $7-15 \mathrm{~m}$ deep. The sponges were placed into sterile plastic and stored in a coolbox for microbiological analysis, in the department of microbiology, Faculty of mathematics and natural sciences, Bogor Agricultural University (FMIPAIPB). Sponge was identified using a sponge identification portal on (http://www.spongeguide. org).

\section{Sample preparation and isolation of sponge- associated bacteria}

Sponge at a mass of $1 \mathrm{~g}$ was sampled and 
weighed in order to isolate the bacteria. The sponge surface was washed with sterile water, crushed and diluted through several dilution levels $\left(10^{-1}\right.$ to $\left.10^{-7}\right)$, and $1.0 \mathrm{~mL}$ of each dilution was plated on both seawater complete (SWC) and zobel marine agar (ZMA) medium. The inoculated plates were incubated at $\pm 27{ }^{\circ} \mathrm{C}$ for $24 \mathrm{~h}$. The colonies were then characterized and purified on SWC or ZMA medium.

\section{Antibacterial assay}

The antibacterial activity of bioactive compounds against pathogenic bacteria was performed by the plate casting method with SWC or ZMA media. Pathogenic bacteria cultured in $1 \mathrm{~mL}$ of liquid medium and incubated for 18-24 $\mathrm{h}$, was collected and plated on $100 \mathrm{~mL}$ sterile SWC or ZMA medium. Once the media was dense, bacteria isolates (previously purified) was streaked onto (single streak) plates, which contained pathogenic bacteria culture test, and then incubated for $24 \mathrm{~h}$ at $\pm 27{ }^{\circ} \mathrm{C}$. Antibacterial activity was indicated by the formation of clear zones around the potential isolate colonies.

\section{Hemolytic assay}

The potential bacteria isolate producing antibacterial compounds were tested for their hemolysis ability using blood medium. The bacterial isolate was streaked on blood agar and incubated for $24 \mathrm{~h}$ at $\pm 27{ }^{\circ} \mathrm{C}$. Haemolytic activity was marked by the formation of clear zones around the bacterial colony.

\section{Pathogenicity test of the bacteria isolate}

Pathogenicity test was performed on post L. vannamei shrimp larvae (in vivo) by adding bacterial suspension $\left(10^{6} \mathrm{cell} / \mathrm{mL}\right)$ to the rearing medium. The shrimp were then placed into $2 \mathrm{~L}$ jars (filled with sterile sea water) at a density of 10 shrimp/L and fed on Artemia (3-5 individuals/ $\mathrm{mL}$ ) four times per day. The test lasted for five days and shrimp mortality was determined on a daily basis, which was compared to the control treatment (without bacterial suspension) at the end of the test (Widanarni et al., 2008b).

\section{$\mathrm{LC}_{50}$ value determination in Vibrio harveyi}

Median lethal concentration $\left(\mathrm{LC}_{50}\right)$ value determination was carried out in order to determine $V$. harveyi bacteria concentration to be used in the challenge test, which can cause the death of at least half of the total tested shrimp. Thus, the infection was done by adding
$V$. harveyi bacterial suspension at different densities $\left(10^{6}, 10^{5}, 10^{4}\right.$, and $10^{3}$ cell $\left./ \mathrm{mL}\right)$ to the rearing water and a control test (without $V$. harveyi bacterial suspension). Shrimp were kept into jars (containing $1 \mathrm{~L}$ of sterile sea water) at a density of 10 shrimp/L and each treatment (different densities) was replicated three times. The observation period lasted for seven days and shrimp survival level was determined on a daily basis.

\section{Challenge test on post larvae of $L$. vannamei}

The potential bacterial isolate at a density of $10^{6}$ cell $/ \mathrm{mL}$ was added to the rearing media a day after the shrimp (at a density of 10 shrimp/ jar) were acclimatized to their media (jars, filled with $2 \mathrm{~L}$ sterile sea water). After a $6 \mathrm{~h}$ co-culture (with shrimp), $V$. harveyi isolate at a density of $10^{5}$ cell $/ \mathrm{mL}\left(\mathrm{LC}_{50}\right)$ was then added to the rearing media and the experiment was replicated three times, included both negative (uninoculated) and positive (inoculated with $V$. Harveyi addition) controls (Widanarni et al., 2008b). The test lasted for ten days and post larvae Pacific white shrimp survival rate was calculated using Effendie (1997) formula at the end of the test.

Survival $(\%)=\mathrm{Nt} / \mathrm{No} \times 100$

Note:

Survival $=$ fish survival $(\%)$

$\mathrm{Nt}=$ number of shrimp at the end of the experiment (individual)

No = number of shrimp at the beginning of the experiment (individual)

\section{DNA genome isolation}

The potential bacterial isolates were cultured on SWC medium, and incubated in a shaking incubator at $100 \mathrm{rpm}$ at $30{ }^{\circ} \mathrm{C}$ for $24 \mathrm{~h}$. A total of $1.5 \mathrm{~mL}$ of bacterial suspension was transferred into a sterile micro tube and centrifuged at 10,000 rpm for ten min and the genomic DNA was isolated using Genomic DNA Mini Kit (Blood/ Cultured Cell). The procedures were carried out according to the manufacturer's instruction (Geneaid, Taiwan).

\section{Amplification of 16S-rRNA, PKS and NRPS genes}

The 16S-rRNA gene was amplified using 1387R primer (5'-GGGCGGWGTGTACAAGGC-3') and 63F primer (5 '-CAGGCCTAACACATGCAAGTC-3') 
(Marchesi et al., 1998) with a targeted fragment of $1,300 \mathrm{bp} .50 \mu \mathrm{L}$ was used as the total reaction volume, consisting of GoTaq Green Mastermix 2x (Promega, Madison, USA) $25 \mu \mathrm{L}, 1387 \mathrm{R}$ and 63F primers $5 \mu \mathrm{L}$ each $(10 \mathrm{pmol})$, DNA template 2 $\mu \mathrm{L}(\sim 100 \mathrm{ng})$ and Nuclease free Water (NFW) 13 $\mu \mathrm{L}$. Amplification was performed using T1-PCR thermocycler (Biometra, Goettingen, DE) and PCR conditions followed Marchesi et al. (1998) method with modifications in pre-denaturation $\left(94{ }^{\circ} \mathrm{C}, 5 \mathrm{~min}\right)$, denaturation $\left(94{ }^{\circ} \mathrm{C}, 30 \mathrm{~s}\right)$, annealing $\left(55^{\circ} \mathrm{C}, 45 \mathrm{~s}\right)$, elongation $\left(72{ }^{\circ} \mathrm{C}, 1 \mathrm{~min}\right.$ $30 \mathrm{sec}$ ). Denaturation, annealing, and elongation were repeated as many as 30 cycles in the post elongation $\left(72{ }^{\circ} \mathrm{C}, 10 \mathrm{~min}\right)$ and cooling $\left(4^{\circ} \mathrm{C}, 5\right.$ min) phases.

Amplification of KS and A domains encoding gene was done by PCR mix consisting of: Gotaq Green Mastermix 2x (Promega, Madison, USA) $25 \mu \mathrm{L}$, each $5 \mu \mathrm{L}$ primer, DNA template $(\sim$ $100 \mathrm{ng}) 2 \mu \mathrm{L}$ and NFW $13 \mathrm{uL}$. Primer for A domain was (coded MTF and MTR) forward: 5'-AARDSIGGIG-SIGSITAYBICC-3', and reverse: 5' CKRWAICCICKIAIYTTIAYYTG-3', meanwhile, KS domain was (coded KSF and KSR) forward: 5'-CSATGGAYCCSCARCARC GSVT-3', reverse: 5'-GTSCC-SGTSCCRTGS SCYTCSAC-3' (Schirmer et al., 2005). PCR conditions followed Schirmer et al. (2005) method with modifications in pre-denaturation $\left(94{ }^{\circ} \mathrm{C}, 5 \mathrm{~min}\right)$, denaturation $\left(94{ }^{\circ} \mathrm{C}, 1 \mathrm{~min}\right)$, annealing $\left(55{ }^{\circ} \mathrm{C}, 1 \mathrm{~min}\right)$, elongation $\left(72{ }^{\circ} \mathrm{C}, 1\right.$ min) processes. Denaturation, annealing, and elongation were repeated for 30 cycles in the post elongation $\left(72{ }^{\circ} \mathrm{C}, 10 \mathrm{~min}\right)$ and cooling $\left(4^{\circ} \mathrm{C}, 5\right.$ $\mathrm{min})$. PCR products visualization was performed by electrophoresis using $1 \%$ agarose gel and DNA molecules staining was carried out using ethidium bromide (EtBr). The results were observed and interpreted using a UV transilluminator.

\section{Bioinformatics analysis}

The amplified product was sequenced using of 1st Base (PT Genetics Science Indonesia) services. The 16S-rRNA gene sequence was aligned with a sequence in the GenBank database using BLAST-N, while the PKS and NRPS gene sequences were analyzed by BLAST-X contained in NCBI (www.ncbi.nlm.nih.gov/BLAST/). Phylogenetic tree Construction was carried out using molecular evolutionary genetics analysis program (MEGA) version 6.0 with the NeighborJoining method (Tamura et al., 2013).

\section{Data analysis}

One-way analyses of variances (ANOVA) was used to determine significant differences among the mean values of pathogenicity of bacterial isolate and $V$. harveyi challenge test in post larvae shrimp (at a lelvel of confidence of 95\%). An ANOVA test was followed by Duncan's post-hoc comparison test using SPSS 15.0 at a level of 5\% $(\alpha=0.05)$ if significant differences were found

\section{RESULTS AND DISCUSSION}

\section{Sponge identification}

Sponge used in this study were identified as Aaptos sp. and Hyrtios sp. The former sponge was classified in the Suberitidae family, the Hadromerida order and the Demospongiae class, and morphologically characterized by a yellowish brown color, hard consistency, and a round shape. While the latter was classified in the Thorectidae family, Dictyoceratida order and Demospongiae class, and was characterized by soft contour surface with grayish black color, a tube like a shape and a relatively soft consistency.

\section{Sponge-associated bacteria isolation and antibacterial activity}

Sponge-associated bacteria isolation was carried out using two types of medium, SWC and ZMA, which are commonly used in isolating sea bacteria. A total of 174 bacterial isolates was isolated from the sponges, consisting of 80 bacterial isolates from Aaptos sp. and 94 bacterial isolates from Hyrtios sp. These medias were used in order to obtain a large variety of bacteria so that the chance of achieving symbiont bacteria able of synthesizing bioactive compounds increased as well. SWC and ZMA were reported to be optimum for isolating microbial symbionts with diverse type of colonies (Yoghiapiscessa $e t$ al., 2016).

Bacterial isolates were further tested to determine their antibacterial activity against B. subtilis, E. coli, V. parahaemolyticus, V. vulnificus and $V$. harveyi. The clear zone that formed around bacterial colony indicates the inhibitory activities against tested bacteria might be due to the production of bioactive compounds from sponge-associated bacteria. $69(40 \%)$ out of 174 bacterial isolates showed antibacterial activity from narrow to a broad spectrum. The antibacterial activities of both bacterial isolated from Aaptos sp. and Hyrtios sp. sponges were $26 \%$ (21 isolates out of 80 isolates) and 51\% 
(48 isolates out of 94 isolates), respectively. The majority of the sponge-associated bacteria (from Aaptos sp.) was shown to have the ability to inhibit $V$. parahaemolyticus (14 isolates) and $E$. coli (10 isolates). Bacteria isolated from Hyrtios sp. was also observed to inhibit E. coli and $V$. parahaemolyticus (31 isolates).

Previous studies reported that spongeassociated bacteria may potential as antimicrobial compounds producers. Nearly $32 \%$ (45 isolates) from a total of 138 bacteria were isolated from the Stylotella sp. sponge, on Bira Island (Thousand Island), which were known for their ability to inhibit the tested microorganism (Yoghiapiscessa et al., 2016). 158 isolates were obtained from nine type of sea sponges in Brazil and 12 isolates (about 9\%) were reported to have inhibitory activity against at least one of the tested microorganisms (Santos et al., 2010). In general, sponge-associated bacteria isolated from Hyrtios sp. have greater inhibitory effect against targeted bacteria compared to bacterial isolates from Aaptos sp. The number of potential isolates bioactive antibacterial properties will certainly engender different results due to several factors such as sponge species, habitat, methods, media selection and potential of each sponge group (Yoghiapiscessa et al., 2016).

\section{Hemolysis ability}

In the present study, 22 isolates showed positive hemolysis that produce antibacterial compounds, signifying that a total of 47 isolates may be used for further analysis. Isolates having the ability to lyse red blood cells (indicated by the formation of clear zone around the colonies) were not considered for subsequent analyses, since the clear zone indicates hemolytic activity (hemolysin production), indicating that the bacteria suspected pathogens in human and animal.

\section{Pathogenicity test of bacterial isolates}

Twelve bacterial Isolates, having a broad spectrum (in the antibacterial activity test) and a negative hemolysis, were selected for the pathogenicity test. Post larvae Pacific white shrimp that were given the selected bacteria isolates showed significant difference in terms of survival compared to both positive and negative controls, indicating that not all the tested isolates were pathogenic to post larvae Pacific white shrimp (Figure 1). The survival of post larvae Pacific white shrimp that were given the potential isolate was quite high (87.5-95.0\%), while the survival of the positive controls, which were given $V$. harveyi, $V$. vulnificus, and $V$. parahaemolyticus, were $32.5 \%, 50 \%$, and $35 \%$, respectively. The survival in the negative controls, which were supplemented with nonpathogenic bacteria and without bacteria, were $87.5 \%$ and $92.5 \%$, respectively. According to Widanarni et al. (2008b), if the survival based on pathogenicity test of the bacteria treatment does not significantly different compared to the control, it means that the tested bacteria do not cause significant mortality or they are classified as not pathogenic.

\section{$\mathrm{LC}_{50}$ value determination and Vibrio harveyi challenge test on post-larvae of $L$. vannamei}

$\mathrm{LC}_{50}$ determination was aimed at obtaining the $V$. harveyi bacterial cells concentration to be used

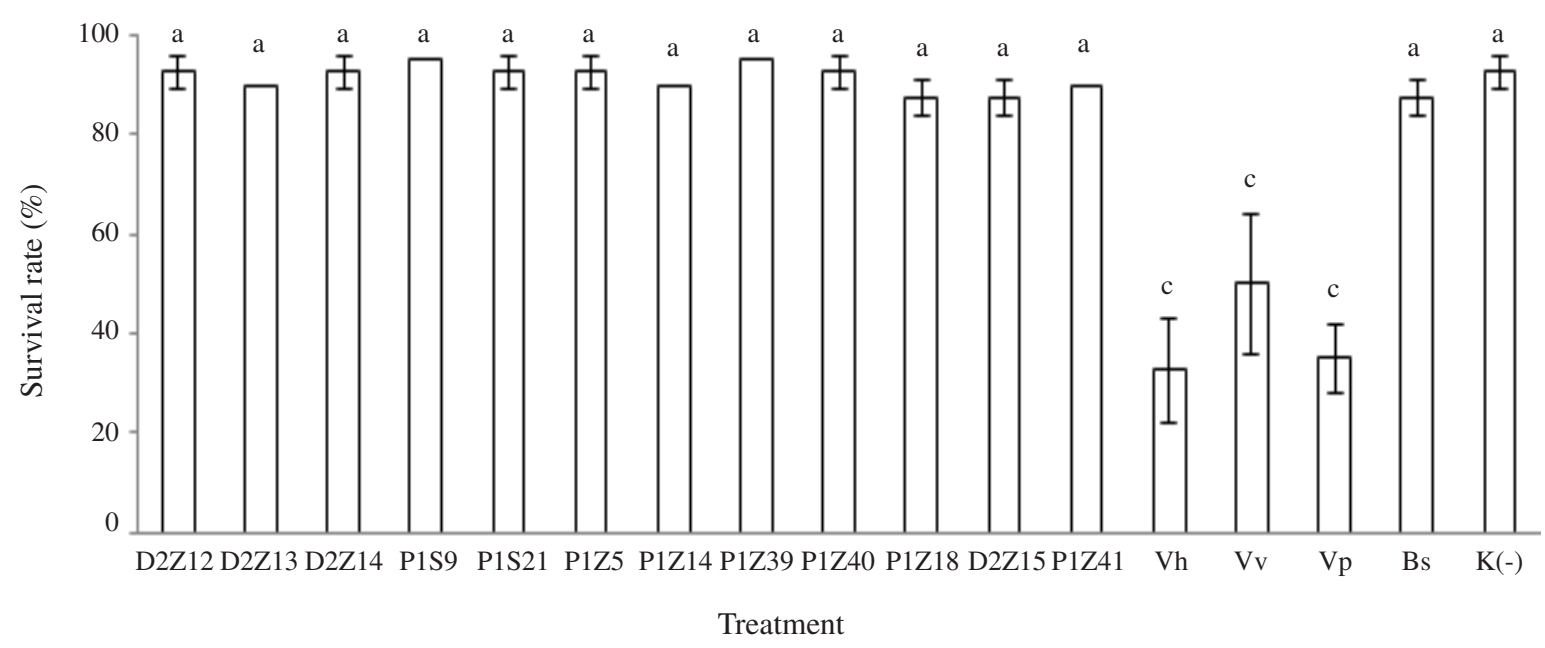

Figure 1. Post larvae Pacific white shrimp survival rate in pathogenicity test (potential bacteria isolates at a cell concentration of $10^{6}$ cell/mL, (Vh) V. harveyi; (Vv) V. vulnificus; (Vp) V. parahaemolyticus. 
in the challenge test, since the mentioned test would lead to the bacterial cells concentration that can cause mortality of at least half the tested shrimp. The $\mathrm{LC}_{50}$ value was $10^{5} \mathrm{cell} / \mathrm{mL}$ in the present study.

Six bacterial isolates were selected, based on the survival (highest) in the pathogenicity test, for further test with $V$. harveyi (on post larvae shrimp). The post larvae shrimp treated with the selected bacterial isolates resulted in significant difference in terms of survival rate compared to the positive control $(\mathrm{P}<0.05)$. However, these results, when compared to the negative control, significantly differed in the bacterial isolates coded P1.S9 P1.Z39. No significant differences were observed between bacterial isolates coded P1.S21, P1.Z5, D2.Z12, and P1.Z40. Post larvae survival rate of the selected bacterial isolates ranged from $70.0 \pm 5.0$ to $90.0 \pm 0.0 \%$, meanwhile, positive (inoculated with $V$. harveyi) and negative controls were $38.3 \pm 2.9 \%$ and $70.0 \pm 5.0 \%$, respectively (Figure 2).

The increase in post larvae shrimp survival rate could be a consequence of $V$. harveyi growth inhibition by bacteria isolates. Widanarni et al. (2008a) Research regarding the addition of Pseudoalteromonas piscicida bacteria $1 \mathrm{Ub}, \mathrm{V}$. alginolyticus SKT-b and Ua at a concentration of $10^{6} \mathrm{CFU} / \mathrm{mL}$ in post larvae tiger shrimp rearing water resulted in survival rates of $88.33 \%$, $83.33 \%$ and $81.67 \%$, respectively. However, the positive control treatment inoculated with $V$. harveyi engendered a survival rate of $41.67 \%$, while the negative control (without bacteria) was about $68.33 \%$. Probiotic isolates such as $1 \mathrm{Ub}$,
SKT-b, and Ua can effectively inhibit $V$. harveyi growth and significantly increase the survival rate in tiger shrimp larvae. The increase in survival rate was due to $V$. harveyi growth inhibition by probiotic bacteria through (possibly) attachment point or nutrients competition (Widanarni et al., 2010).

\section{Amplification of 16S-rRNA NRPS-PKS gene and bioinformatics analysis}

The 16S-rRNA gene amplification of six potential isolates showed DNA fragment in size $\sim 1,300$ bp (Figure 3). The phylogenetic tree was constructed using the neighbor-joining method with a bootstrap of 1,000 . Phylogenetic tree construction of the 16S-rRNA gene was conducted to determine the relationship between bacterial isolates and strains from the GenBank database. The result showed the formation of two types of clade i.e. a group of Gram-negative bacteria (first clade), consisting of Pseudomonas and Alcaligenes genus and a group of Grampositive bacteria (second clade), consisting of the Staphylococcus genus (Figure 4).

Amplification of NRPS and PKS genes of potential bacterial isolates resulted in DNA fragment length of $\sim 1,000 \mathrm{bp}$ and $700 \mathrm{bp}$, respectively (Figure 5 and 6). DNA fragment alignment results of NRPS gene using BlastX program showed a low identity for both $\mathrm{A}$ and KS domains in the data GenBank, 42-94\% and $78-95 \%$, respectively (Table 1). Detection of NRPS and PKS genes in four potential isolates showed that four isolates have NRPS gene only, and one isolate having the PKS gene only and one

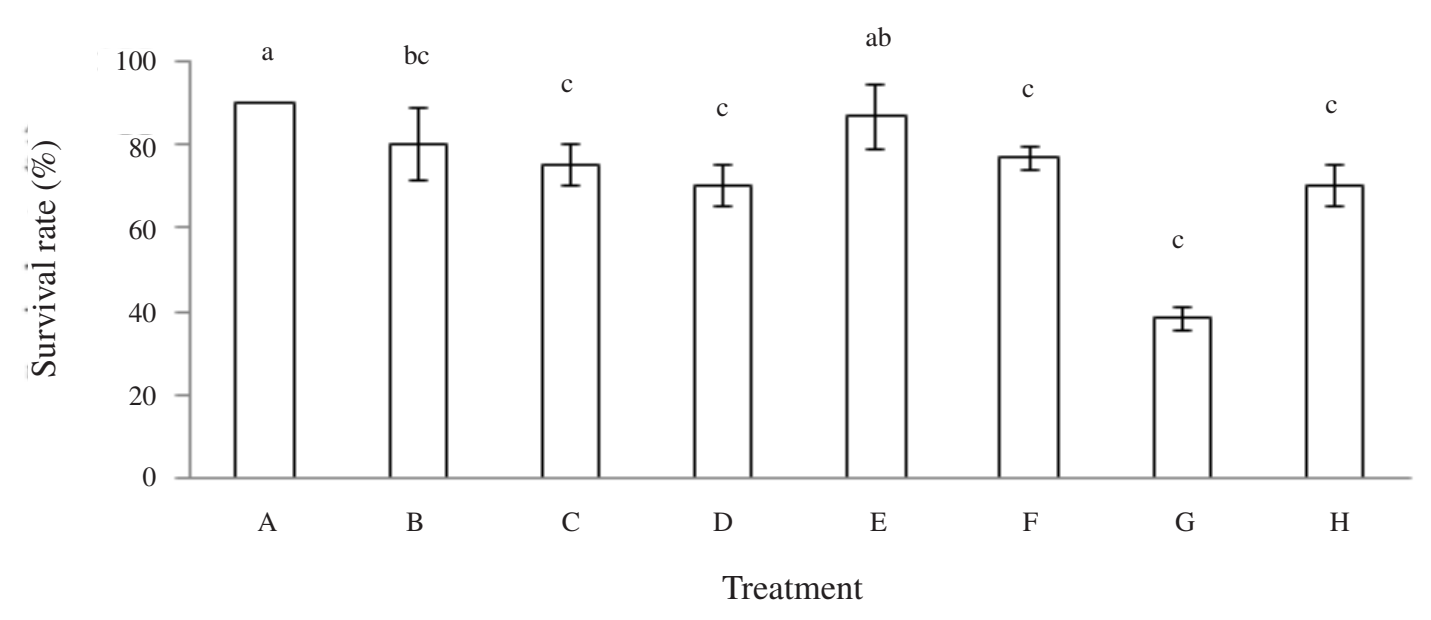

Figure 2. Post-larval vaname shrimp survival in Vibrio harveyi potential bacteria test, (A) P1.S9 + Vh; (B) P1.S21 + Vh; (C) P1.Z5 + Vh; (D) D2.Z12 + Vh; (E) P1.Z39 + Vh; (F) P1.Z40 + Vh; (G) positive control (Vh); (H) negative control. Different numbers following the letters with the same pattern indicate no significant differences based on Duncan's multiple range test (DMRT) at 5\% level. 


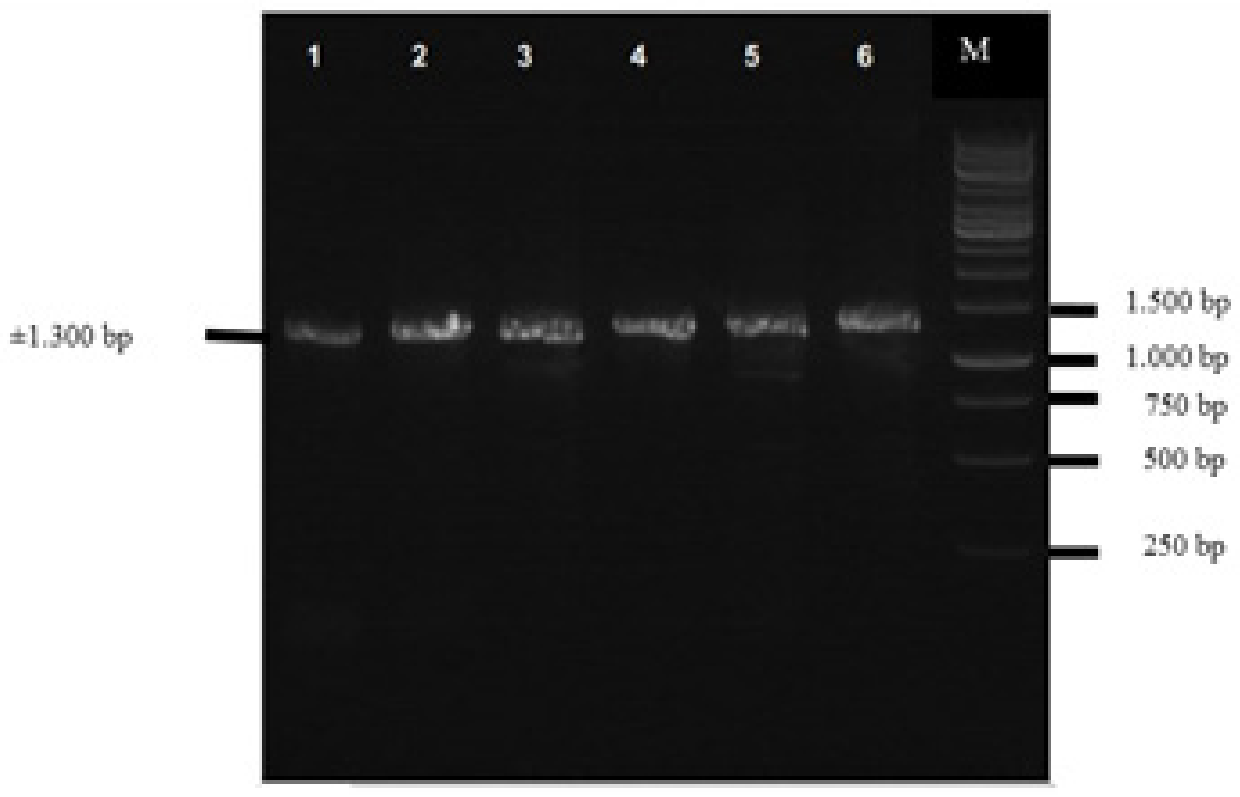

Figure 3. 16S-rRNA PCR amplification, band of bacterial DNA size 1,300 bp with (M) marker $1 \mathrm{~kb},(1)$ D2.Z12, (2) P1.S9, (3) P1.S21, (4) P1.Z5, (5) P1.Z40, (6) P1.Z39.

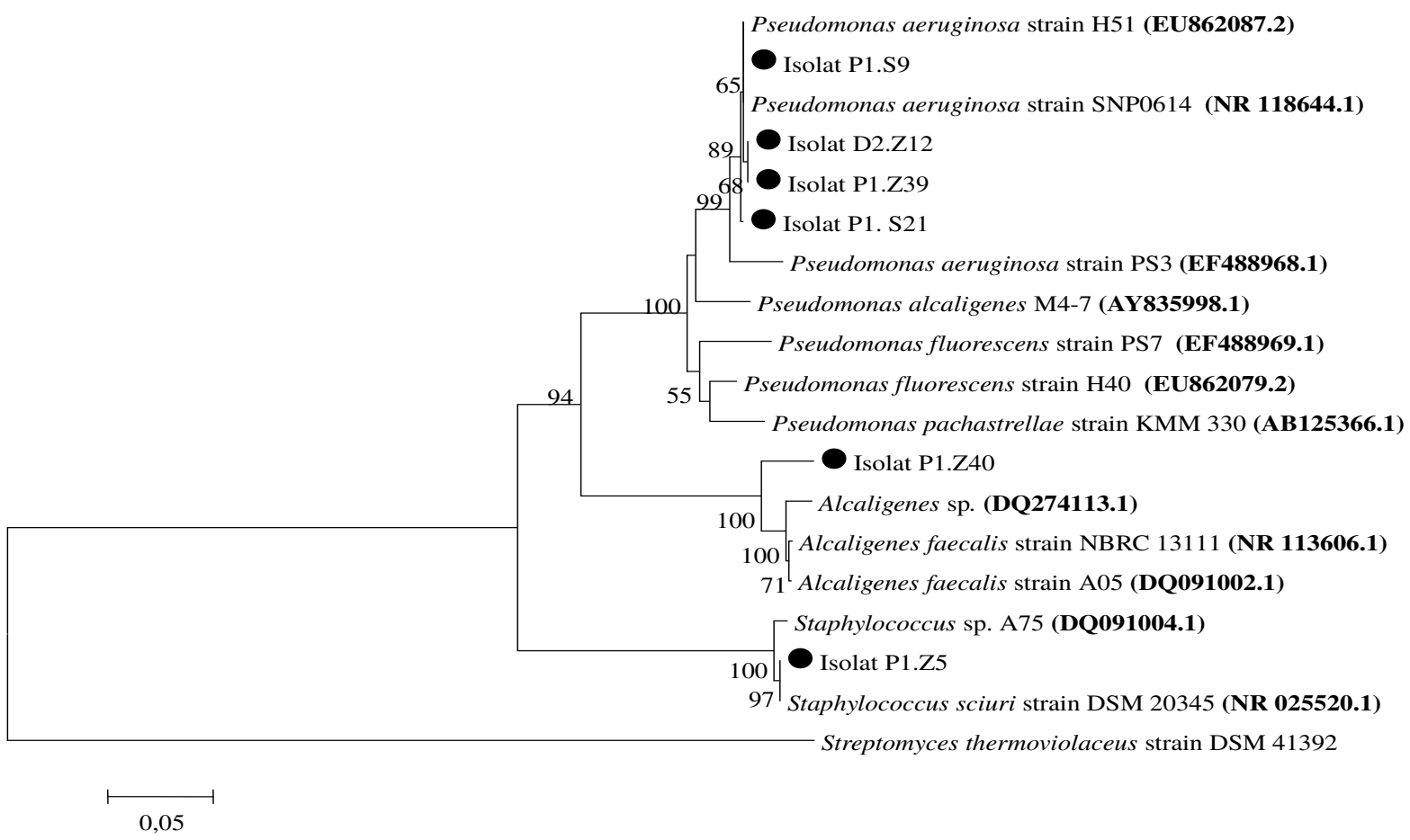

Figure 4. Phylogenetic tree based on 16S-rRNA sequence constructed with Neighbor-Joining method and a bootstrap of 1,000. The number 0.05 at the bottom of the tree shows the relationship distance scale.

isolate having both NRPS and PKS genes.

The bacteria that could potentially produce bioactive compounds are characterized by the presence of PKS and NRPS genes. NRPS and PKS enzymes are quite large (about 200 to 2,000 $\mathrm{kDa}$ ) and work as multifunctional enzymes that play roles in bioactive compound synthesis
(Moffit \& Neilan, 2003). NRPS-PKS hybrid may occur with a combination of NRPS module domain with a PKS module domain in a single open reading frame. Hybrid NRPS-PKS genes have the ability to produce a new type of bioactive compounds with hybrid structure (Zhu et al., 2009). 


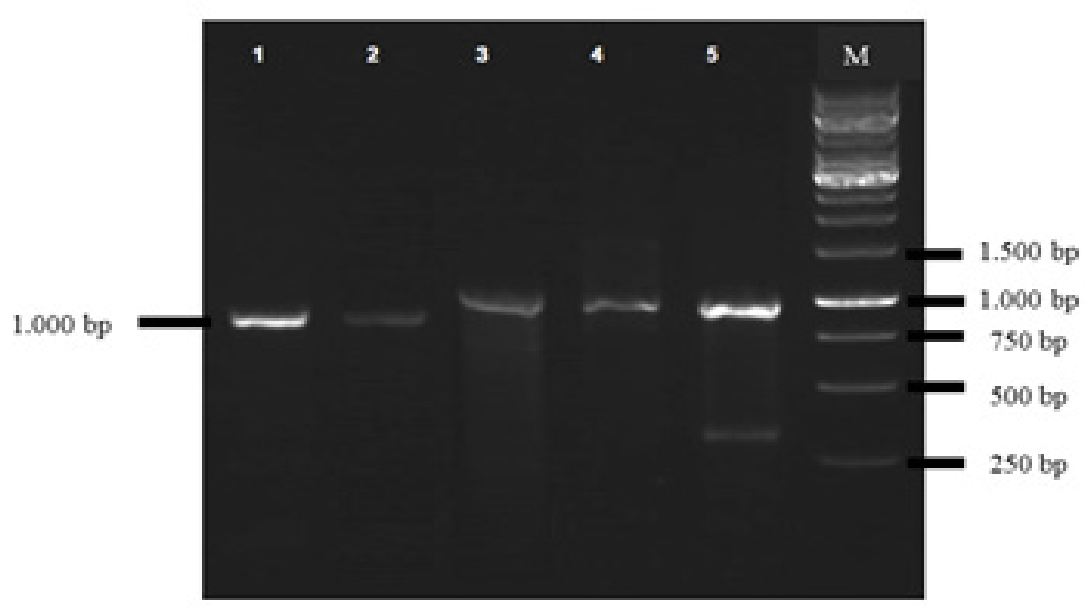

Figure 5. Domain (A) PCR amplification results in the encoding bacterial NRPS enzyme isolat gene, DNA band measuring 1,000 bp with (M) marker $1 \mathrm{~kb}$, (1) P1.Z5, (2) P1.Z39, (3) P1.S21, (4) P1.S9, (5) D2.Z12.

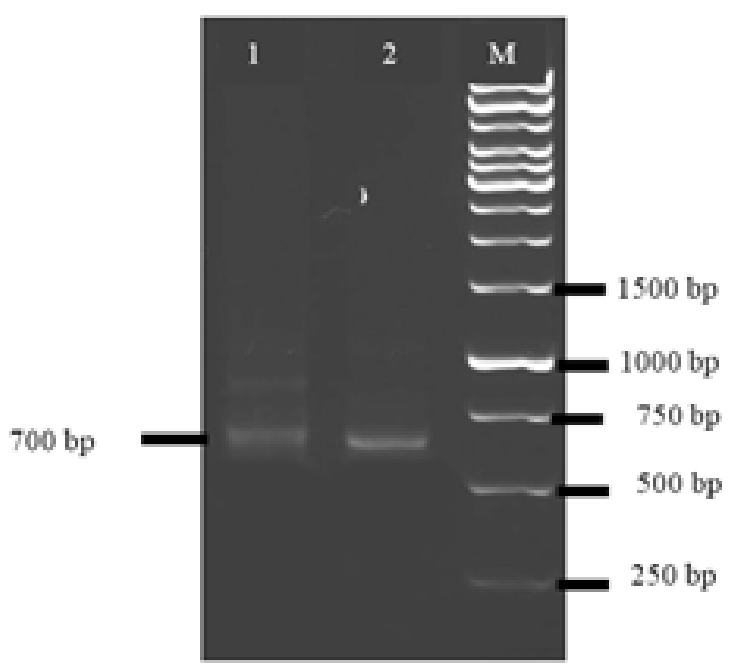

Figure 6. (KS) PCR amplification results in the encoding bacterial PKS enzyme gene, DNA band measuring 700 bp with (M) marker $1 \mathrm{~kb}$, (1) P1.Z39, (2) P1.Z40.

Table 1. Bioinformatics analysis of gene encoding A (NRPS) and KS (PKS) domain.

\begin{tabular}{|c|c|c|c|c|c|}
\hline $\begin{array}{l}\text { Isolate } \\
\text { code }\end{array}$ & Closest relative & Identity (\%) & E-value & $\begin{array}{l}\text { Query } \\
\text { cover }\end{array}$ & $\begin{array}{l}\text { Accession } \\
\text { Number }\end{array}$ \\
\hline P1.Z5 & $\begin{array}{l}\text { Non-ribosomal peptide synthetase; } \\
\text { Pseudomonas aeruginosa }\end{array}$ & $42 \%$ & $1 e-36$ & 91 & WP 059303316.1 \\
\hline P1.Z39 & $\begin{array}{l}\text { Non-ribosomal peptide synthetase; } \\
\text { Pseudomonas aeruginosa }\end{array}$ & $43 \%$ & $2 \mathrm{e}-40$ & 91 & KPE43450.1 \\
\hline P1.S21 & $\begin{array}{l}\text { Non-ribosomal peptide synthetase; } \\
\text { Pseudomonas aeruginosa MPAO1/P2 }\end{array}$ & $94 \%$ & $6 e-169$ & 97 & EHS41779.1 \\
\hline P1.S9 & $\begin{array}{l}\text { Non-ribosomal peptide synthetase; } \\
\text { Pseudomonas aeruginosa MPAO1/P2 }\end{array}$ & $73 \%$ & 1e-112 & 96 & EHS41779.1 \\
\hline D2.Z12 & $\begin{array}{l}\text { Non-ribosomal peptide synthetase; } \\
\text { Pseudomonas aeruginosa }\end{array}$ & $42 \%$ & $2 \mathrm{e}-13$ & 40 & WP 051527643.1 \\
\hline P1.Z39 & $\begin{array}{c}\text { Type I polyketide synthase WcbR; } \\
\text { Alcaligenes faecalis }\end{array}$ & $95 \%$ & $4 e-88$ & 70 & WP 003805497.1 \\
\hline P1.Z40 & $\begin{array}{l}\text { Type I polyketide synthase WcbR; } \\
\text { Alcaligenes faecalis }\end{array}$ & $78 \%$ & $3 e-115$ & 99 & WP 063691887.1 \\
\hline
\end{tabular}




\section{CONCLUSION}

Sponge-associated bacteria isolated from Aaptos sp. and Hyrtios sp. from Pramuka Island showed antibacterial activity based on in vitro tests against B. subtilis, E. coli, V. parahaemolyticus, $V$. harveyi, and $V$. vulnificus. Six potential isolates were determined through pathogenicity and challenge tests against $V$. harveyi (in vivo) and their 16S-rRNA gene sequence analysis were belong to Pseudomonas aeruginosa strain SNP0614 (code P1.S9, P1.S21, D2.Z12, P1.Z39), Staphylococcus sciuri DSM 20345 (code P1.Z5) and Alcaligenes faecalis strain NBRC 13111 (code P1.Z40). Four potential bacterial isolates have been detected to have the NRPS gene only, and one isolate has the PKS gene only and one isolate has both NRPS and PKS genes.

\section{ACKNOWLEDGEMENTS}

Part of this research was funded by the Center for Marine and Fisheries Education, Ministry of Marine Affairs and Fisheries Republic of Indonesia.

\section{REFERENCES}

Abubakar H, Wahyudi AT, Yuhana M. 2011. Skrining bakteri yang berasosiasi dengan spons Jaspis sp. sebagai penghasil senyawa antimikroba. Ilmu Kelautan 16: 35-40.

Aguirre-Guzmán G, López-Acevedo EA, Vázquez-Sauceda MDL.2013. Vibrio harveyi effect under survival of Litopenaeus vannamei larvae. Scientia Agropecuaria 4: 121-127.

Austin B. 2010. Vibrios as causal agents of zoonoses. Veterinary Microbiology 140: $1-34$.

Chatterjee S, Haldar S. 2012. Vibrio related diseases in aquaculture and development of rapid and accurate identification methods. Journal Marine Sciene Research Developement S1: 1-7.

Effendie MI. 1997. Metoda Biologi Perikanan. Yogyakarta, Indonesia: Yayasan Pustaka Nusatama.

Felix F, Nugroho TT, Silalahi S, Octavia Y. 2011. Screening of Indonesian original bacteria Vibrio sp. as a cause of shrimp diseases based on 16s ribosomal DNA-technique. Jurnal Ilmu dan Teknologi Kelautan Tropis 3: 85-99.

Isnansetyo A, Istiqomah I, Muhtadi, Sinansari S, Hernawan RK, Triyanto, Widada J. 2009.
A potential bacterial biocontrol agent, strain S2V2 against pathogenic marine Vibrio in aquaculture. World Journal Microbiology Biotechnology 25: 1103-1113.

Marchesi JR, Sato T, Weightman AJ, Martin TA, Fry JC, Hiom SJ, Wade WG. 1998. Design and evaluation of useful bacterium-specific PCR primer that amplify genes coding for bacterial 16S rRNA. Applied Environmental Microbiology 64: 795-799.

Mayer AMS, Rodríguez AD, Berlinck RGS, Fusetani N. 2011. Marine pharmacology in 2007-8: Marine compounds with antibacterial, anticoagulant, antifungal, anti-inflammatory, antimalarial, antiprotozoal, antituberculosis, and antiviral activities; affecting the immune and nervous system, and other miscellaneous mechanisms of action: review. Comparative Biochemistry Physiology 153: 191-222.

Moffit MC, Neilan BA. 2003. Evolutionary affiliations within the superfamily of ketosynthases reflect complex pathway associations. Journal Molecular Evolution 56: 446-457.

Nofiani R, Nurbetty S, Sapar A. 2009. Antimicrobial activites of methanol extract from unidentified sponge associated bacteria in Lemukutan Island, Kalimantan Barat. Jurnal Ilmu dan Teknologi Kelautan Tropis 1: 33-41.

Santos OCS, Pontes PVML, Santos JFM, Muricy G, Giambiagi-deMarval M, Laport MS. 2010. Isolation, characterization and phylogeny of sponge associated bacteria with antimicrobial activities from Brazil. Research Microbiology 161: 604-612.

Schirmer A, Gadkari R, Reeves CD, Ibrahim F, Delong EF, Hutchinson CR. 2005. Metagenomic analysis reveals diverse polyketide synthase gene cluster in microorganisme associated with the marine sponge Discodermia dissoluta. Applied Environmental Microbiology 71: 4840-4849.

Tamura K, Stecher G, Peterson D, Filipski A, Kumar S. 2013. MEGA6: Molecular evolutionary genatics analysis version 6.0. Molecular Biology Evolution 30: 2725-2729.

Taylor MW, Radax R, Steger D, Wagner M. 2007. Sponge-associated microorganisms: evolution, ecology, and biotechnological potential. Microbiology Molecular Biology Reviews 71: 295-347.

Widanarni, Ayuzar E, Sukenda. 2008a. Inhibitory mechanism of robiotic bacteria on the growth 
of Vibrio harveyi in tiger shrimp Penaeus monodon larvae. Jurnal Akuakultur Indonesia 7: 179-188.

Widanami,Sukenda,SetiawatiM.2008b.Probiotic bacte-ria in shrimp cultures: its selection, mechanism of action, characterization, and application as a biocontrol agent. Jurnal llmu Pertanian Indonesia 13: 80-89.

Widanarni, Lidaenni MA, Wahjuningrum D. 2010. Effects of different doses of skt-b vibrio probiotic bacteria addition on survival and growth rate of tiger shrimp Penaeus monodon larva. Jurnal Akuakultur Indonesia 9: 21-29.
Yoghiapiscessa D, Batubara I, Wahyudi AT. 2016. Antimicrobial and antioxidant activities of bacterial extracts from marine bacteria associated with sponge Stylotella sp. American Journal Biochemistry Biotechnology 12: 3646.

Zhu, Peng, Zheng Y, Yan X, Shao J. 2009. Molecular phylogeny and modular structure of hybrid NRPS/PKS gene fragment of Pseudoteromonas sp. NJ6-3-2 isolated from marine sponge Hymeniacidon perleve. Journal Microbiology Biotechnology 19: 229-237. 